\title{
Infection by Neospora caninum in dairy cattle belonging to family farmers in the northern region of Brazil
}

\author{
Infecção por Neospora caninum em bovinos leiteiros de agricultores familiares da região norte do Brasil \\ Ricardo Vilas Boas ${ }^{1,2}$; Thábata dos Anjos Pacheco ${ }^{1}$; Andréia Lima Tomé Melo ${ }^{1}$; Anderson Castro Soares de Oliveira ${ }^{1}$; \\ Daniel Moura de Aguiar ${ }^{1}$; Richard de Campos Pacheco ${ }^{1 *}$ \\ ${ }^{1}$ Programa de Pós-Graduação em Ciências Veterinárias, Faculdade de Agronomia, Medicina Veterinária e Zootecnia, Universidade \\ Federal de Mato Grosso - UFMT, Cuiabá, MT, Brasil \\ ${ }^{2}$ Empresa de Assistência Técnica e Extensão Rural do Estado de Rondônia - EMATER-RO, Ji-Paraná, RO, Brasil
}

Received February 7, 2015

Accepted March 23, 2015

\begin{abstract}
Neosporosis is considered a major cause of abortion among cattle worldwide. The aim of this study was to investigate the prevalence of anti-Neospora caninum antibodies in dairy cattle and correlate them with possible risk factors on 63 small farms (family farms) in the municipality of Ji-Paraná, the main milk-producing region of the state of Rondônia, northern Brazil. For this purpose, 621 serum samples were collected from cows and were evaluated by means of the indirect fluorescence antibody test (IFAT). The overall herd prevalence of $N$. caninum antibodies among the farms $(38 / 63 ; 60.31 \%)$ showed that $N$. caninum are widespread among the dairy herds in this region, despite only infecting a small proportion of animals $(66 / 621,10.62 \%)$. Occurrences of abortion and birth of weak calves were the only variables that showed as risk factors for the presence of $N$. caninum. The result from the spatial lag model strongly indicated that birth of weak calves and presence of $N$. caninum are occurring on farms that are located close to each other, indicating aggregation of disease occurrence.
\end{abstract}

Keywords: Neospora caninum, prevalence, family farming, Amazon.

\section{Resumo}

Neosporose é considerada uma das principais causas de aborto em rebanhos bovinos em todo o mundo. O objetivo deste estudo foi investigar a prevalência de anticorpos anti-Neospora caninum em bovinos de leite e correlacioná-los com possíveis fatores de risco em 63 pequenas propriedades rurais (agricultura familiar), no município de Ji-Paraná, uma das principais regiôes produtoras de leite do Estado de Rondônia, norte do Brasil. Para este propósito, 621 amostras de soro foram coletadas de vacas leiteiras e avaliadas por meio da reaçáo de imunofluorescência indireta (RIFI). A prevalência total de propriedades com animais positivos a anticorpos anti- $N$. caninum $(38 / 63 ; 60,31 \%)$ indica que o parasito está difundido entre os rebanhos leiteiros da região, apesar de infectar uma pequena proporção de animais (66/621; 10,62\%). Ocorrência de abortos e nascimento de bezerros fracos foram as únicas variáveis consideradas como fatores de risco para a ocorrência de $N$. caninum. O resultado do modelo de análise espacial indica que o nascimento de bezerros fracos e a presença de $N$. caninum estão aparecendo em fazendas localizadas próximas umas das outras, indicando a ocorrência de agregação da doença.

Palavras-chave: Neospora caninum, prevalência, agricultura familiar, Amazônia.

\section{Introduction}

Many factors affect livestock production and productivity. The economic performance of dairy activity is directly related to the reproductive rates of the herd, and these rates may be affected by several

*Corresponding author: Richard de Campos Pacheco. Departamento de Ciências Básicas e Produção Animal - DCBPA, Faculdade de Agronomia, Medicina Veterinária e Zootecnia - FAMEVZ, Universidade Federal de Mato Grosso - UFMT, Av. Fernando Corrêa da Costa, 2367, Boa Esperança, CEP 78060-900, Cuiabá, MT, Brasil.

e-mail: richard@ufmt.br other characteristics, such as the individuals' physiology, genetics, nutrition and general health (LAMY et al., 2012). Reproduction diseases of livestock are multifactorial, widespread throughout the Brazilian herd and caused by both infectious and noninfectious agents. Infectious diseases may be associated with bacterial, viral or parasitic agents. In Brazil, these diseases may commonly include brucellosis, leptospirosis, infectious bovine rhinotracheitis (IBR), bovine viral diarrhea (BVD), ureaplasmosis (BUZINHANI et al., 2007) and neosporosis (MENDES et al., 2009). 
Since the first description of Neospora caninum as a new genus and species in 1988, bovine neosporosis has become a disease of international concern, given that it is among the main causes of abortion in cattle (ALMERÍA, 2013). Although $N$. caninum has a wide host range, it is considered primarily to be a disease of cattle and dogs (DUBEY \& SCHARES, 2011).

Infection by $N$. caninum is prevalent in a wide variety of domestic and wild animals in different countries (DUBEY \& SCHARES, 2011). The serological prevalence of $N$. caninum antibodies in dairy cattle in Brazil has been shown to range from 13.7\% (AGUIAR et al., 2011) to $91.2 \%$ (MINERVINO et al., 2008).

Knowledge of the risk factors for herds to acquire $N$. caninum infection, and thus become exposed to $N$. caninum-associated abortion, is important with regard to development and implementation of measures to control bovine neosporosis (DUBEY et al., 2007). The present study aimed to carry out a serological-epidemiological study on $N$. caninum infection and evaluate risk factors for this infection, among dairy cattle in rural areas in the municipality of Ji-Paraná, Rondônia, considering the nature and social organization of farms operated on a family-run basis.

\section{Materials and Methods}

\section{Study site}

This study was conducted in the municipality of Ji-Paraná, located in the state of Rondônia, in the western Brazilian Amazon region, which is the third largest milk producer in the state.
The sampling premises took into consideration six strata of milk production (rural sectors), in accordance with data from the Technical Assistance and Rural Extension Association of the State of Rondônia (EMATER-RO) (Figure 1).

\section{Sampling procedures}

Serum samples were collected from dairy cows of reproductive age ( $\geq 24$ months old), among the population of dairy cows on family farms. Samples were selected in each stratum, considering two stages: farms and dairy cows. In determining the number of farms to be sampled, both the number of farms and the number of animals in each sector were taken into consideration (Table 1). To select the stages of the main sample, a systematic draw was conducted among the farms in each sector, along with a draw among the dairy cows.

\section{Samples and health questionnaire}

Serum samples were obtained from dairy cows on 63 farms between September 2012 and November 2013 (Table 1). A sample of 10 dairy cows from each farm was established (primary sampling unit). Overall, 621 samples from dairy cows were collected (three farms did not reach the number of ten cows for sampling). Simultaneously with collection of blood samples from cattle, blood was collected from all dogs $(n=177)$ present on 61 of the 63 farms (Table 1). The responsible for each farm answered a questionnaire addressing epidemiological factors relating to $N$. caninum.

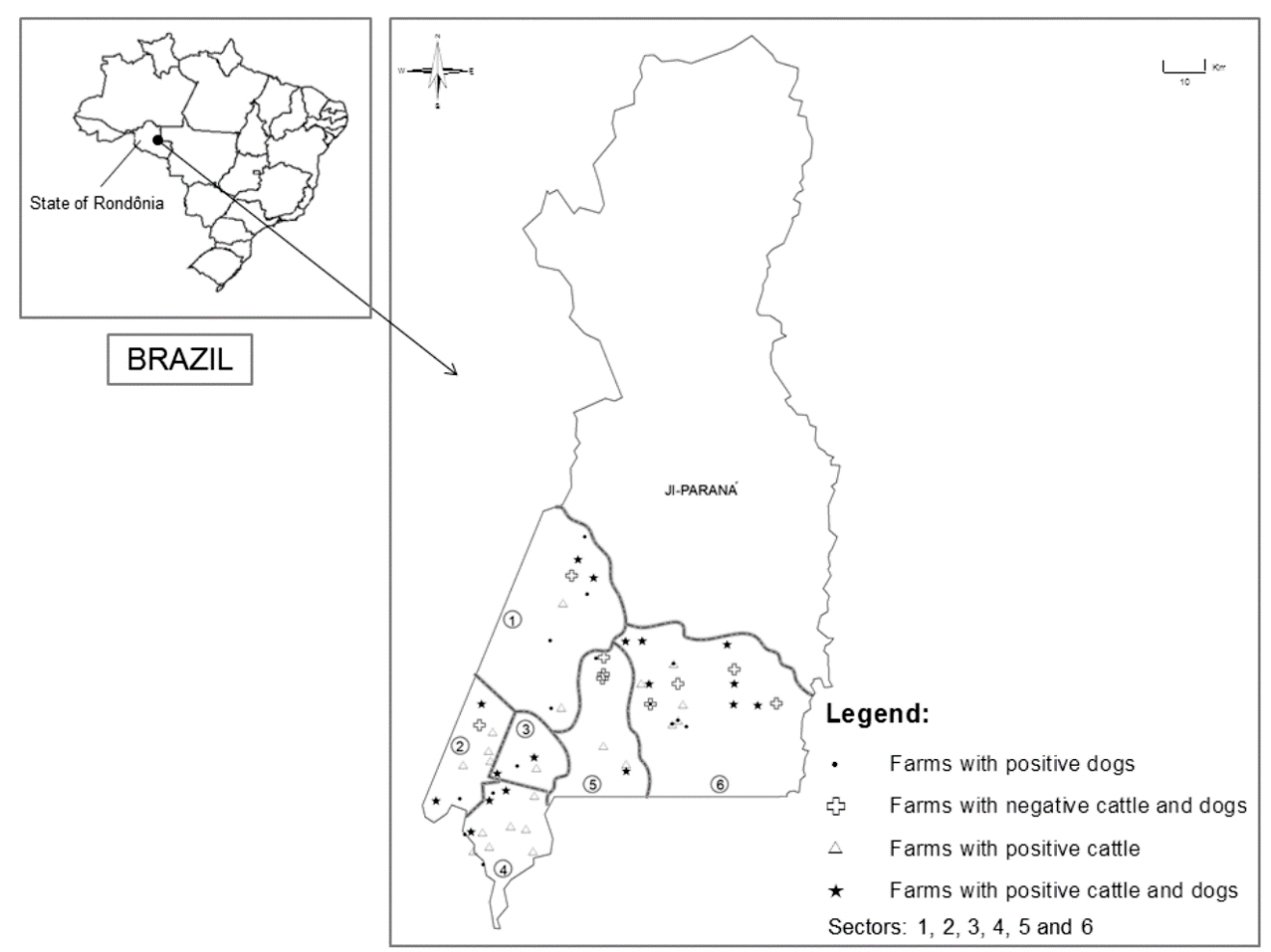

Figure 1. Distribution of family farms, taking into consideration six strata of milk production (rural sectors), in accordance with data from the Technical Assistance and Rural Extension Association of the State of Rondônia (EMATER-RO), Ji-Paraná, Rondônia. 
Table 1. Number of family farms, number of cows (= 24 months of age), number of farms and dogs sampled per rural sector, from September 2012 to November 2013, of the municipality of Ji-Paraná, Rondônia, Brazil.

\begin{tabular}{cccccc}
\hline Sector & Number of farms & $\begin{array}{c}\text { Number of dairy } \\
\text { cows }\end{array}$ & $\begin{array}{c}\text { Number of farms } \\
\text { sampled }\end{array}$ & $\begin{array}{c}\text { Number of dairy } \\
\text { cows sampled }\end{array}$ & $\begin{array}{c}\text { Number of dogs } \\
\text { sampled }\end{array}$ \\
\hline 1 & 122 & 5,246 & 9 & 90 & 26 \\
2 & 124 & 5,952 & 9 & 85 & 23 \\
3 & 54 & 2,268 & 4 & 40 & 130 \\
4 & 176 & 8,096 & 13 & 108 & 35 \\
5 & 143 & 4,433 & 11 & 168 & 24 \\
6 & 237 & 8,532 & 63 & 621 & 55 \\
\hline
\end{tabular}

\section{Laboratory analysis}

The levels of $N$. caninum antibodies were measured by means of the indirect fluorescent antibody test (IFAT) in accordance with Dubey et al. (1988), using the cutoff dilutions of 1:100 for cattle and 1:50 for dogs (AGUIAR et al., 2006). Reactions in which tachyzoites presented total peripheral fluorescence were deemed positive (PARÉ et al., 1998). All the seropositive serum samples were retested using two-fold serial dilutions. Positive and negative control samples were included on each slide.

\section{Prevalence and statistical analysis}

The sample size was determined by the statistical formula $N_{o}=\left[N p(1-p) /(N-1)\left(d / Z_{\alpha / 2}\right)^{2}+p(1-p)\right]$.deff. The population size considered was 34527 animals; the prevalence was estimated to be $50 \%$ (given that there were no previous studies and that the maximum number of occurrences with normal distribution would be at the $50 \%$ mark); maximum error of 5\%; 95\% confidence interval; and design effect (deff) of 1.5. The sample size was 570 animals, and this was adjusted upwards by $10 \%$ to account for the possibility of losses, to a total of 627 animals (approximately 10 animals for each farm, on 63 properties), with weighting according to the sampling design, taking into consideration the probabilities of selection among the farms and animals. The complete sample design taking the sectors of the municipality and the number of farms into consideration is shown in Table 1.

Statistical analyses were performed using the $\mathrm{R}$ statistical package (R DEVELOPMENT CORE TEAM, 2013), packages survey (LUMLEY, 2014) and spdep (BIVAND et al., 2013). The associations between positivity for $N$. caninum antibodies and the variables were analyzed by means of the chi-square $\left(\chi^{2}\right)$ test, with significance of $5 \%$. The covariate variables analyzed were: presence of dogs; dogs positive for $N$. caninum on farm; occurrence of abortion; birth of weak calves; cattle with access to forest; wild canids nearby; dogs with access to cattle food; dogs with access to water for cattle; dogs with access to remains of dead cattle carcasses; dogs feeding on commercial food or meals; dogs that get stuck or loose; cattle grazing with dogs present; total number of cattle; number of cows over 24 months of age; size of farm (hectares); destination of the dead animals; and destination of fetuses, when observed.

A spatial lag model (Spatial AutoRegressive, SAR) was constructed as described by Câmara et al. (2002), using the formula:
$Y=\rho W Y+X \beta+\varepsilon$, to analyze the spatial relationship and the factors that influenced occurrences of $N$. caninum. $W$ is the neighborhood matrix, and expressing the product $W Y$ spatial dependence in $Y, X$ is matrix of covariates and $\rho$ is the autoregressive spatial coefficient. The null hypothesis for the absence of autocorrelation is that $\rho=0$. In this analysis, the variable $Y$ was taken to be the proportion of positive animals per farm, using the formula $Y=$ no. positive/ no. sampled. We took into consideration the following covariates: presence of dogs (yes or no); total number of animals on the farm property; occurrences of abortion on the farm (yes or no); access of dogs to cattle food (yes or no); and occurrence of weak calves (yes or no). In order to obtain a summarized model considering only the significant variables, we tested all variables together and separately.

The Bioethical Committee for Animal Research of the Federal University of Mato Grosso approved the present study, under protocol no. 23108.015662/12-5.

\section{Results}

From the total sample, antibodies to $N$. caninum were detected in 66 of the 621 examined cows, with a prevalence of $10.62 \%$ (95\% CI; 8.04-13.86). Antibody titers ranging from 100 to 1,600 with $22(33.33 \%)$ samples showed titer of $100 ; 21(31.82 \%)$ titer of $200 ; 16(24.24 \%)$ titer of 400 ; three $(4.55 \%)$ titer of 800 ; and four $(6.06 \%)$ titer of 1,600 .

The overall prevalence per herd was $60.31 \%$ with 38 of the 63 farms with at least one seropositive animal. Antibodies to $N$. caninum were found in $42 \mathrm{dogs}(23.72 \%)$, with titers ranging from 50 to 3,200. Seropositive dogs were found on 28 (44.44\%) of the 63 farms examined. In all six sectors of the municipality, $N$. caninum positive dogs and dairy cows were observed (Figure 1).

Univariate correlations between examined variables and the presence of dairy cows positive for $N$. caninum showed that abortion and birth of weak calves were associated with occurrences of $N$. caninum antibodies on the farms studied (Table 2).

In the spatial lag model, only the covariate of occurrences of weak calves was considered significant, and on farms on which occurrences of weak calves were reported, the proportion of animals positive for $N$. caninum was 0.0742 times greater. There was a positive correlation ( $\mathrm{p}<0.0001)$, indicating aggregation of occurrences of $N$. caninum. Thus, the spatial lag model is $Y=0.6408 \mathrm{WY}+0.0742 F$, where $F$ is occurrence of weak calves. 
Table 2. Univariate associations between animal characteristics and presence of positivity for $\mathrm{N}$. caninum by means of IFAT, among dairy cows, from September 2012 to November 2013, in the municipality of Ji-Paraná, Rondônia, Brazil.

\begin{tabular}{lllll}
\hline \multirow{2}{*}{$\begin{array}{c}\text { Characteristics of } \\
\text { the farm }\end{array}$} & \multicolumn{3}{c}{$\begin{array}{c}\text { Farms with positive } \\
\text { Cattle positive }\end{array}$} & \multirow{2}{*}{$\mathbf{P}^{*}$} \\
\cline { 2 - 4 } & Yes & No & \% positivos & \\
\hline $\begin{array}{l}\text { Occurrences of abortion } \\
\quad \text { Yes }\end{array}$ & 26 & 10 & 72.22 & \\
$\quad$ No & 12 & 15 & 44.44 & $0.0257^{*}$ \\
Birth of weak calves & & & & \\
$\quad$ Yes & 20 & 06 & 76.00 & \\
No & 18 & 19 & 48.65 & $0.0239^{*}$ \\
\hline
\end{tabular}

${ }^{*}$ Chi-square test.

\section{Discussion}

This study was designed to analyze a particular production system, the family farming. The overall herd prevalence of $N$. caninum antibodies $(60.31 \%)$, with 38 of 63 presenting positive animals and showing that $N$. caninum are widespread among the dairy herds in this region, despite only $10.62 \%$ of the animals are positive. Studies on $N$. caninum antibody seroprevalence have been conducted both in Brazil and in several other parts of the world. However, caution is needed in evaluating these results because of differences in serological techniques, study design, sample size, diagnostic techniques and cutoff points, and because the background of the samples analyzed is not always known (GUIMARÁES et al., 2004; DUBEY et al., 2007). Nonetheless, Aguiar et al. (2006), also with a cutoff value of 1:100, detected prevalence of $11.2 \%$ in dairy herds and $70.0 \%$ on dairy farms from Monte Negro municipality, central area of the state of Rondônia, close to the region of the present study. The major difference between this study and Aguiar et al. (2006) refers to management. In the present study only five farms $(7.94 \%)$ reported regular veterinary care, while in the previous study farms were larger and with high levels of technification, however the prevalence values were similar.

Extensive rearing of animals was observed on 51 (80.95\%) of the farms, characterized by deficient and unrefined animal handling that included poor use of hygienic-sanitary measures and lack of technology. Moreover, the low prevalence of $N$. caninum could be related to the extensive management to which dairy cows are subjected, once $80.95 \%$ of farms reported to follow this system, and in this type of management the probability of contact with oocysts is lower than in dairy cattle kept under more confined conditions (ARMENGOL et al., 2007).

Occurrences of abortion and birth of weak calves were the only risk factors for occurrence of $N$. caninum on the farms $(\mathrm{p}<0.05)$. There was a significant association between seropositivity for $N$. caninum and occurrences of abortions among dairy cows, thus reinforcing the role of $N$. caninum as a major cause of reproductive disorders (DUBEY et al., 2006; BRUHN et al., 2013; GHALMI et al., 2012). It is important to note that the reproductive problems described on 36 farms (57.14\%) were occurrences of abortions, while on 26 (41.26\%), they consisted of birth of weak calves, among which some evolving to death. Abortion is the main clinical manifestation of bovine neosporosis in dairy cattle, and depending on the stage of pregnancy, this can lead to abortion or the birth of a healthy but chronically infected calf (DUBEY et al., 2006). However, an additional study should be performed to analyze the aborted fetus and weak calves to confirm the infection and lesions by $N$. caninum.

In most epidemiological studies on dairy herds, the presence of farm dogs has been a risk factor for seropositivity among cattle (PARÉ et al., 1998; GUIMARÃES et al., 2004; DUBEY et al., 2007; GHALMI et al., 2012). This is not surprising, since dogs are the definitive hosts of $N$. caninum, which can shed environmentally resistant oocysts. However, because $N$. caninum-associated abortions are not always linked to horizontal transmission but also occur in chronically infected dams, it cannot be expected that there is always a positive association between the presence or number of farm dogs and bovine abortion (DUBEY et al., 2007).

Antibodies to $N$. caninum were found in 42 dogs (23.72\%). In 28 (44.44\%) of 63 farms were observed at least one seropositive dog, but there was no association between the presence of seropositive dairy cows and the presence of dogs or the presence of dogs positive for $N$. caninum on farms. Similarly, Guimarães et al. (2004) and Bruhn et al. (2012) reported frequencies of seropositive, respectively, among dogs in rural areas of Paraná (21.6\%), and Minas Gerais (29.9\%). Aguiar et al. (2006) detected (also with a cutoff value of 1:50), among 172 dogs from rural area of Monte Negro, Rondônia lower percentage (12.6\%) and, as reported in our study, did not also observed the presence of farm dogs as a risk factor for seropositivity among cattle.

The result from the spatial lag model strongly indicated that birth of weak calves and presence of $N$. caninum are occurring on farms that are located close to each other. With dynamics of this nature, local differences are small and regional differences are large because nearby properties tend to have the same behavior. Figure 1 shows the proximity of positive farms. In fact, it is possibly to observe this characteristic of aggregation of disease occurrence among farms in sectors two, three and four. It was noteworthy that the rural properties in the study area were characterized by small size, such that $55(87.30 \%)$ of them comprised less than 100 ha. Thus, this aggregated behavior may be related to the characteristics of the farms studied, which according to their sizes and close proximity, may allow transit of infected dogs between farms thus spreading $N$. caninum infection to nearby farms.

\section{Conclusion}

This study observed the infection and distribution of $N$. caninum in dogs and dairy cattle herds in the municipality of Ji-Paraná, Rondônia, which is one of the major dairy production areas in the western Amazon region. In addition, reproductive problems such as abortion and birth of weak calves were associated with occurrences of neosporosis in cattle on dairy farms. The result from the spatial lag model strongly indicated that birth of weak calves and presence of $N$. caninum are occurring on farms that are located close to each other, indicating aggregation of disease occurrence. 


\section{Acknowledgements}

To the Technical Assistance and Rural Extension Association of the State of Rondônia (EMATER-RO) for technical support. We thank to Conselho Nacional de Desenvolvimento Científico e Tecnológico (CNPq) for the scholarships of D. M. Aguiar and R. C. Pacheco. We thank to Coordenaçáo de Aperfeiçoamento de Pessoal de Nível Superior (CAPES) for the scholarships of A. L. T. Melo, T. A. Pacheco, and for the financial support.

\section{References}

Aguiar DM, Cavalcante GT, Rodrigues AAR, Labruna MB, Camargo LMA, Camargo EP, et al. Prevalence of anti-Neospora caninum antibodies in cattle and dogs from Western Amazon, Brazil, in association with some possible risk factors. Vet Parasitol 2006; 142(1-2): 71-77. http://dx.doi. org/10.1016/j.vetpar.2006.06.014. PMid:16857319.

Aguiar DM, Lacerda DP, Orlandelli RC, Medina AO, Azevedo SS, Okuda LH, et al. Seroprevalence and risk factors associated to Neospora caninum in female bovines from the western São Paulo State, Brazil. Arq Inst Biol 2011; 78(2): 183-189.

Almería S. Neospora caninum and Wildlife. Parasitology 2013; 1-23. Article ID 947347.

Armengol R, Pabón M, Santolaria P, Cabezón O, Adelantado C, Yániz $\mathrm{J}$, et al. Low seroprevalence of Neospora caninum infection associated with the limousin breed in cow-calf herds in Andorra, Europe.J Parasitol 2007; 93(5): 1029-1032. http://dx.doi.org/10.1645/GE-1242R.1. PMid:18163335.

Bivand RS, Hauke J, Kossowski T. Computing the Jacobian in Gaussian spatial autoregressive models: An illustrated comparison of available methods. Geogr Anal 2013; 45(2): 150-179. http://dx.doi.org/10.1111/ gean. 12008 .

Bruhn FRP, Daher DO, Lopes E, Barbieri JM, Rocha CM, Guimarães AM. Factors associated with seroprevalence of Neospora caninum in dairy cattle in southeastern Brazil. Trop Anim Health Prod 2013; 45(5): 1093 1098. http://dx.doi.org/10.1007/s11250-012-0330-y. PMid:23212838.

Bruhn FRP, Figueiredo VC, Andrade GS, Costa-Júnior LM, Rocha CMBM, Guimarães AM. Occurrence of anti-Neospora caninum antibodies in dogs in rural areas in Minas Gerais, Brazil. Rev Bras Parasitol Vet 2012; 21(2): 161-164. http://dx.doi.org/10.1590/S1984-29612012000200017. PMid:22832759.

Buzinhani M, Metiffogo E, Timenetsky J. Detecção de Mycoplasma spp. e Ureaplasma diversum em vacas com distúrbios reprodutivos. Arq Bras Med Vet Zootec 2007; 59(6): 1368-1375. http://dx.doi.org/10.1590/ S0102-09352007000600003.
Câmara G, Carvalho MS, Cruz OG, Correa V. Análise espacial de áreas [online]. INPE; 2002 [cited 2014 Dec 10]. Available from: http:// mtc-m12.sid.inpe.br/col/sid.inpe.br/sergio/2005/02.17.14.42/doc/ cap5-areas $1 \% 5$ b1\%5d.pdf

Dubey JP, Buxton D, Wouda W. Pathogenesis of bovine neosporosis. J Comp Pathol 2006; 134(4): 267-289. http://dx.doi.org/10.1016/j. jcpa.2005.11.004. PMid:16712863.

Dubey JP, Hattel AL, Lindsay DS, Topper MJ. Neonatal Neospora caninum infection in dogs: isolation of the causative agent and experimental transmission. J Am Vet Med Assoc 1988; 193(10): 1259-1263. PMid:3144521.

Dubey JP, Schares G, Ortega-Mora LM. Epidemiology and control of neosporosis and Neospora caninum. Clin Microbiol Rev 2007; 20(2): 323-367. http://dx.doi.org/10.1128/CMR.00031-06. PMid:17428888.

Dubey JP, Schares G. Neosporosis in animals--the last five years. Vet Parasitol 2011; 180(1-2): 90-108. http://dx.doi.org/10.1016/j.vetpar.2011.05.031. PMid:21704458.

Ghalmi F, China B, Ghalmi A, Hammitouche D, Losson B. Study of the risk factors associated with Neospora caninum seroprevalence in Algerian cattle populations. Res Vet Sci 2012; 93(2): 655-661. http:// dx.doi.org/10.1016/j.rvsc.2011.12.015. PMid:22244708.

Guimarães JS Jr, Souza SL, Bergamaschi DP, Gennari SM. Prevalence of Neospora caninum antibodies and factors associated with their presence in dairy cattle of the north of Paraná state, Brazil. Vet Parasitol 2004; 124(1-2) 1-8. http://dx.doi.org/10.1016/j.vetpar.2004.07.002. PMid:15350656.

Lamy E, van Harten SV, Sales-Baptista E, Guerra MMM, Almeida AM. Factors influencing livestock productivity. In: Sejian V, Naqvi SMK, Ezeji T, Lakritz J, Lal R. Environmental stress and amelioration in livestock production. Berlin Heidelberg: Springer-Verlag; 2012. p. 19-51.. http:// dx.doi.org/10.1007/978-3-642-29205-7_2.

Lumley T. Survey: analysis of complex survey samples. 2014. R package version 3.30 .

Mendes MB, Bittar JFF, Pereira WAB, Arduino GGC, Bittar ER, Panetto JCC, et al. Determinaçáo da prevalência das principais doenças da reproduçấo no rebanho bovino da região de Uberaba-MG. Ciênc Anim Bras 2009; (Suppl S1): 772-777.

Minervino AH, Ragozo AM, Monteiro RM, Ortolani EL, Gennari SM. Prevalence of Neospora caninum antibodies in cattle from Santarém, Pará, Brazil. Res Vet Sci 2008; 84(2): 254-256. http://dx.doi.org/10.1016/j. rvsc.2007.05.003. PMid:17619028.

Paré J, Fecteau G, Fortin M, Marsolais G. Seroepidemiologic study of Neospora caninum in dairy herds. J Am Vet Med Assoc 1998; 213(11): 1595-1598. PMid:9838960

$\mathrm{R}$ Development Core Team. R: a language and environment for statistical computing, reference index version 2.14.0. Vienna: R Foundation for Statistical Computing; 2013 [cited 2014 Dec 11]. Available from: http:// www.R-project.org 